\author{
Małgorzata MIKŁOSZ ${ }^{1}$ \\ Teresa PIECUCH ${ }^{2}$ \\ Elżbieta SZCZYGIEL ${ }^{3}$ \\ Ana BARROCA ${ }^{4}$
}

\title{
CULTURAL CONDITIONS FOR INDIVIDUAL AND CORPORATE ENTREPRENEURSHIP DEVELOPMENT
}

\begin{abstract}
The article focuses on characterizing the two kinds of entrepreneurship - individual and corporate. Their development is the result of a combination of various factors, dependent - both - on the internal (subjective) predispositions of particular individuals who themselves conduct business activities (individual entrepreneurship) and the persons realizing entrepreneurial ventures (corporate entrepreneurship), as well as on the external conditions determining the rate of entrepreneurship development and influencing the effectiveness of this kind of activities. In the study, the subject of the in-depth analysis is the issue of cultural conditions for individual and corporate entrepreneurship development. The authors of the paper draw the attention to the fact that the analysis of entrepreneurship (both - theoretical and empirical) cannot disregard its connection to culture, which creates solid foundations for any human activity, including entrepreneurial activity. Entrepreneurship is a social process which is strongly determined by culture. It depends on patterns and the values that are shaped historically on the level of a family as well as local communities. J. Schumpeter indicated that entrepreneurship development requires a favorable social climate. Presently, cultural conditions are considered to have the fundamental role in the development of all types of entrepreneurship. It is emphasized that entrepreneurship is deeply rooted in and completely shaped by culture. Hence, the analysis of entrepreneurship (also individual and corporate ones) cannot disregard its relations to culture.
\end{abstract}

Keywords: entrepreneurship, individual entrepreneurship, corporate entrepreneurship, organisational culture

\section{INTRODUCTION}

Entrepreneurship is a multidimensional phenomenon, which can be analysed at the level of individuals, groups, organisations as well as regions, countries and economies. In each case, the analysis of entrepreneurship cannot (should not) fail to take into consideration its connection to culture. Hence, as a social phenomenon, it requires the research that exceeds economic, formal, legal, technical, etc. conditions. It should take into account cultural context and the relations in working groups, since in each case, entrepreneurship, independently from its type, "occurs" in a specified cultural context. Culture constitutes a

\footnotetext{
${ }^{1}$ Małgorzata Mikłosz, PhD Appl., Danmar Computers, ul. K. Hoffmanowej 19, 35-016 Rzeszów, Poland, email:m.miklosz@danmar-computers.com.pl

${ }^{2}$ Teresa Piecuch, PhD, Faculty of Management, Rzeszow University of Technology, Al. Powstanców Warszawy 8, 35-959 Rzeszów, Poland, e-mail:piecuch@ @rz.edu.pl - corresponding author

${ }^{3}$ Elżbieta Szczygieł, PhD, Contact Author, Section of social-economic analysis, Centre for Education and Enterprise Support, ul. K. Hoffmanowej 19, 35-016 Rzeszów, Poland, e-mail: elzbieta.szczygiel@ cwep.eu

${ }^{4}$ Ana Barroca, MSc Appl., Advancis - Business Services Lda., Rua Primeiro de Maio, 192, $2^{\circ}$ Tras 4450-230 Matosinhos, Portugal, e-mail: a.barroca@advancis.pt
} 
basis for its creation and development; it is a driving force for human entrepreneurship. Although it is a very significant aspect, it is not easy to analyse. That has been emphasised, inter alia, by Ł. Sułkowski, who claims that 'organisational culture is a term that constitutes foundations, but simultaneously, a curse for humanities and social sciences' 5 .

The subject of the paper is the issue related to the significance of organisational culture for the development of individual and corporate entrepreneurship. There have been discussed the nature, functions and the significance of organisational culture. There has been also emphasised its role in the process of entrepreneurship ${ }^{6}$.

\section{THE NATURE AND THE SIGNIFICANCE OF ORGANISATIONAL CULTURE}

Organisational culture ${ }^{7}$ is a notion that has many various definitions ${ }^{8}$. According to the narrowest conceptualisation, it is 'certain behaviour, standards and values of a particular individual [...], usual way of thinking, feeling and acting - shared, adopted and assimilated by employees' ${ }^{9}$. The selected definitions depicting the nature of organisational culture are presented in Table 1.

Table 1. The definitions of organizational culture

\begin{tabular}{|c|l|}
\hline Author & \multicolumn{1}{c|}{ Organisational culture is: } \\
\hline L. Sutkowski & $\begin{array}{l}\text { a learned product of group experience, which bases on values, } \\
\text { standards and cultural patterns that ensue from them }\end{array}$ \\
\hline E. H. Schein & $\begin{array}{l}\text { a pattern of shared basis assumption that was learned by aroup as } \\
\text { it solved its problems of external adaptation and internal integra- } \\
\text { tion, which has worked well enough to be considered valid and, } \\
\text { therefore, to be taught to new members as the correct way to per- } \\
\text { ceive, think, and feel in relation to those problems }\end{array}$ \\
\hline M. Kostera & a set of prevailing values and standards of behaviour characteristic \\
\hline
\end{tabular}

\footnotetext{
${ }^{5}$ Ł. Sułkowski, Ewolucjonizm w zarzadzaniu. Menedżerowie Darwina, PWE, Warszawa 2010, p. 71.

${ }^{6}$ The present article has been prepared in connection with the realisation of the project Recruitment for Effective European Cultural Workforce Diversity - REDIVE, realised by Danmar Computers within the scope of the project Erasmus Multilateral, under the direction of The University School of Management and Industrial Studies in Porto, in partnership with Rotterdam School of Management and IESE Business School. The project in question is aimed at analysing intercultural differences in the management process, particularly, at the stage of recruitment, and indicating significant aspects of increasing the effectiveness and satisfaction from working in diversified cultural environment.

${ }^{7}$ The term "organisational culture" itself was probably used for the first time by E. Jacques, who was conducting research in the factory Glacier in 1940s. The cultural perspective at the macro-social level served him as a variable that enabled the explanation of the economic and social problems of colonial countries. However, its permanent place in management sciences organisational culture gained in 1980s - 1990s. This movement developed owing to the influence of the international comparisons of working processes in the USA and Japan source: Ł. Sułkowski, Kulturowa zmienność organizacji, PWE, Warszawa 2002, p. 53 and the following.

${ }^{8}$ It is not an easy task to define organisational culture. E. H. Schein comments on this problem in the following way: "generally, everybody agrees that "it" (which is called organisational culture) exists and that it important in its effects, but when we try to define it, we have completely different ideas of what "it" is'. E. H. Schein emphasises that the problems with defining organisational culture can ensue from various categories that are used to explain its nature, e.g.: 1) group norms; 2) espoused values, formal philosophy; 3) rules of the game; 4) climate; 5) embedded skills; 6) habit of thinking, mental models and linguistic paradigms; 7) shared meanings; 8) formal rituals and celebrations - source: E. H. Schein, Organizational Culture and Leadership, John Wiley \& Sons Publisher, San Francisco 2004, pp. 12, 13

9 M. Czerska, Kulturowe uwarunkowania przedsiębiorczości w badanych przedsiębiorstwach, [in:] „Przedsiębiorczość - natura i atrybuty”, K. Jaremczuka, ed., PWSZ w Tarnobrzegu, Tarnobrzeg 2012, p. 219.
} 


\begin{tabular}{|c|l|}
\hline & $\begin{array}{l}\text { of a particular organisation, underpinned with the assumption on } \\
\text { the nature of reality and which is manifested in artefacts (external, } \\
\text { artificial culture creations) }\end{array}$ \\
\hline K. Bolesta - Kukułka & $\begin{array}{l}\text { unwritten code of values, patterns of organisational behaviour, } \\
\text { symbols, attitudes and orientations of organisation' participants, } \\
\text { which is deeply embedded in organisational culture and passed on } \\
\text { from generation to generation }\end{array}$ \\
\hline J. Kisielnicki & $\begin{array}{l}\text { a set of the elements that are crucial for the functioning of an } \\
\text { organisation, e.g., artefacts, values, norms, policy of an organisa- } \\
\text { tion, which are formed by: employees, traditions and the environ- } \\
\text { ment }\end{array}$ \\
\hline G. Hofstede & $\begin{array}{l}\text { a specific "intellectual refinement", which is manifested in educa- } \\
\text { tion, art and literature }\end{array}$ \\
\hline
\end{tabular}

Source: Ł. Sułkowski, Kulturowa zmienność organizacji, op. cit., p. 58; J. Kisielnicki, Zarzadzanie. Jak zarzadzać $i$ być zarzadzanym, PWE, Warszawa 2008, p. 34 and the following; E. H. Schein, Organizational Culture and Leadership, op. cit., p. 17; G. Hofstede Kultury i organizacje, PWE, Warszawa 2000, p. 39; http://geert-hofstede.com/poland.html [retrieved: July $8,2015]$.

En enormous contribution to the development of the theory of organisational culture was made by a Dutch scholar G. Hofstede, who in 1970s and 1980s conducted complex research in several dozen countries in the world, aiming to determine the influence of culture on the values held in a workplace. Owing to them, he indicated considerable differences between people according to the nationality (which is strictly bounded with culture) they represent. On this basis, he defined the key dimensions of the differences between cultures, taking into consideration the following aspects ${ }^{10}$ :

- power distance index (PDI) - determines the way in which inequalities between people are treated in a society;

- individualism and collectivism (IDV) - is measures the relations of an individual with other people and setting personal freedom against the need of social ties,

- masculinity and femininity (MAS) - concerns the division of social roles by sex. In the masculine society, there is a considerable division of social roles by sex, and in the feminine society there is relatively little division,

- uncertainty avoidance (UAI) - determines the attitude of the society to the uncertainty concerning the future,

- long and short term orientation (LTO) - indicates the manner of viewing the time and the perspective on activity ${ }^{11}$.

The above-mentioned classification is very useful while determining behaviour, preferences and desirable ways of communication with the representatives of a given culture

\footnotetext{
10 G. Hofstede Kultury $i$ organizacje..., op. cit., p. 51; http://geert-hofstede.com/poland.html [retrieved: July 8, 2015].

${ }^{11}$ Originally, G. Hofstede distinguished 4 basic dimensions of organisational culture, namely: 1) power distance, 2) individualism and collectivism, 3) masculinity and femininity, 4) uncertainty avoidance. In 1991, M. Bond together with G. Hofstede diagnosed the fifth differentiating factor - "long and short term orientation". This dimension determined the way of perceiving time and the perspective of action in particular cultures. In 2010, basing on the research conducted by M. Minkov, there were proposed two additional dimensions: "pragmatism and normativism" (PRA) and "indulgence versus self-restraint" (IND). Whereas the former was a completely new category, the latter derived from the long and short term orientation. Thus, in the present research on cultures, G. Hofstede proposes the use of the six dimensions of the differences in organisational culture.
} 
and can be of much help, e.g., in choosing a proper management style, in motivating and planning trainings for groups in accordance to their belonging to a given culture.

Organisational culture performs a range of functions. Undoubtedly, the most significant one is building the identity of a certain community that is conducive to the sense of its belonging, and, therefore, identification with the organisation. What is also important is that it reduces uncertainty and provides greater sense of security which translates into engagement, and therefore, into individual and organisational effectiveness. J. Kisielnicki formulated the functions of organisational culture drawing attention to its significance within an organisation and in reference to the environment. This division is presented in Table 2.

Table 2. Internal and external functions of organisational culture

\begin{tabular}{|c|c|}
\hline Internal functions: & External functions: \\
\hline $\begin{array}{l}\text { offers common language and concep- } \\
\text { tual apparatus, which enable commu- } \\
\text { nication improvement, } \\
\text { establishes the boundaries of activity } \\
\text { of particular groups, determines zones } \\
\text { of influence, } \\
\text { influences people's attitudes and be- } \\
\text { haviour, } \\
\text { informs what is allowed and what for- } \\
\text { bidden, } \\
\text { determines the way the style of power } \\
\text { is realised, } \\
\text { determines the principles of punishing } \\
\text { and rewarding, } \\
\text { increases the sense of security, } \\
\text { offers the ideology that enables em- } \\
\text { ployees to find motivation to activity. }\end{array}$ & $\begin{array}{l}\text { understanding (e.g., by clients, suppli- } \\
\text { ers, shareholders) of organisation's aims } \\
\text { and strategy, } \\
\text { employees' integration and their focus } \\
\text { on means and aims, } \\
\text { the adoption (by owners and employ- } \\
\text { ees) of uniform principles of the evalua- } \\
\text { tion of goals achievement, the function- } \\
\text { ing of the entire organisation and its } \\
\text { particular elements, } \\
\text { the creation of a climate that enables } \\
\text { overcoming threats, and common activ- } \\
\text { ities aiming to change present strategy. }\end{array}$ \\
\hline
\end{tabular}

Source: Own study based on: J. Kisielnicki, Zarzadzanie. Jak zarzadzać i być zarzadzanym, op. cit., p. 37 and the following.

Organisational culture translates into organisation's functioning - it influences the effectiveness since it ${ }^{12}$ :

- enables quick, efficient and unambiguous communication between participants; makes them understand each other better,

- standardises human behaviour increasing foreseeability and replacing immediate control; hence, it enables (to some extent) the resignation from formalisation that stiffens organisations and counteracts entrepreneurship and innovativeness,

- owing to this kind of culture, the members of an organisation interpret and evaluate the surrounding reality and the changes that occur within its scope,

- cultural community causes that organisation's members share aspirations, aims, desires, hopes and fears, which eases tensions connected to crises, conflicts, and heightens the feeling of the success being achieved.

\footnotetext{
${ }^{12}$ A. K. Koźmiński, D. Jamielniak, Zarzadzanie od podstaw, Oficyna Wolters Kluwer business, Warszawa 2011, p. 267.
} 
Therefore, organisational culture is one of the most important factors that stimulate, or restrain (if the management underestimate its importance) organisations' functioning and development. It is also a complex tool for shaping entrepreneurial behaviour and attitudes; a source where emotional, cognitive and behavioural elements of entrepreneurial attitudes come from ${ }^{13}$. It contributes to the creation and the development of "entrepreneurial spirit", owing to which people are more creative and entrepreneurial.

\section{THE ROLE OF ORGANISATIONAL CULTURE IN THE PROCESS OF INDI- VIDUAL ENTREPRENEURSHIP DEVELOPMENT}

Individual entrepreneurship consists in undertaking and running business activity (the establishment of one's own, independent enterprise) by a natural or legal person or other organisational unit that is not a legal person. It is probably historically the oldest depiction of entrepreneurship.

In the literature on the subject, the significance of individual entrepreneurship was for the first time emphasised by R. Cantillon, who identified an entrepreneur with a merchant who buys goods at stable price, but sells at unstable one. The risk that is related to this kind of activity (connected to lack of certainty of activity, inability to anticipate future state and situation in the market) makes - according to R. Cantillon - a merchant an entrepreneur, since they take the risk of this type of activity ${ }^{14}$.

Contemporary theories on entrepreneurship derive from J. Schumpeter's concept, which is considered the prime one. He perceived entrepreneurship and the entrepreneurs implementing innovations as the main accelerator of economic growth and development, and the process of the so-called creative destruction ${ }^{15}$, which constitutes a source of entrepreneurship, as a basis for every positive change that occurs in enterprises and the economy. According to him, this process bases on innovations that destroy the present (yet still working) ways of production, introducing new, improved ones (the process is called moral obsolescence of machines and equipment), simultaneously becoming a source of progress. For J. Schumpeter, innovations are an endogenic driving force for entrepreneurship.

What deserve particular attention in the process of individual entrepreneurship are an entrepreneur and the economic functions they perform. The above mentioned J. Schumpeter called them demiurges, divine economy creators, a source of all positive changes and development. R. F. Hebert and A. N. Link created a list of various functions of an entrepreneur that were available in the literature. These $\operatorname{are}^{16}$ :

- taking risk connected to uncertainty,

- providing (gaining) financial capital,

- the implementation of innovations,

\footnotetext{
${ }^{13}$ A. Pocztowski, Rola systemu zarzadzania kapitatem ludzkim w kształtowaniu przedsiębiorczości. Narzędzia zarzadzania kapitatem ludzkim kreujace postawy przedsiębiorcze, [in:] „Kapitał ludzki a kształtowanie przedsiębiorczości”, M. Juchnowicz, ed., Poltext, Warszawa 2004, p. 236 and the following.

${ }^{14} \mathrm{H}$. Barreto, The Entrepreneur in Microeconomic Theory: Disappearance and Explanation, Routledge, London and New York 1989, p. 34; R. Cantillon, Essai sur la nature du commerce en général, The Royal Economic Society, Londyn 1959, pp. 54-55.

${ }^{15}$ B. R. Barringer, A. C. Bluedorn, The relationship between corporate entrepreneurship and strategic management, „Strategic Management Journal” 1999, No 20, p. 442.

${ }^{16}$ R. F. Hebert, A. N. Link, The Enterepreneur. Mainstream Views and Radical Critiques, Peaeger Special Studies, Praeger Scientific, New York 1982, pp. 107-108.
} 
- making profit,

- decision-making,

- leadership,

- leading, organising and coordinating activities,

- possessing resources that are used to run a business (owned by an enterprise),

- employing factors of production,

- entering into contracts, signing agreements,

- arbitrage of the goods that differ in prices in geographically distant markets performed to gain profit.

One of the more important conditions for individual entrepreneurship development is organisational culture. It determines people's behaviour, the process of interactions between co-workers (partners, employees) - it creates a kind of frameworks of entrepreneurial activity of an individual, a network of behaviour that establishes patterns and standards of conduct. But for organisational culture, no organisation or human activity - also entrepreneurial one - could exist and develop properly. It was already emphasised by J. Schumpeter, who postulated that the development of entrepreneurship, first of all, requires favourable social climate ${ }^{17}$. However, not until now so much importance has been attached to cultural factors, which are considered to have great - if not decisive - significance for the development of entrepreneurial behaviour. It has been emphasised that 'the sources of entrepreneurial cultures lie much deeper than only in the mechanisms of the market - also in culture, patterns and values of a society itself ${ }^{\prime 18}$.

According to H. B. Hawkins, present research on entrepreneurship has been dominated by economists. Although their works do not present its comprehensive image, their scientific output cannot be questioned. As easily observed - claims H. B. Hawkins - many economists omit the issues that constitute the essence of entrepreneurship on purpose: the influence of such social factors as: moral conviction, standards and values that people in various cultures prize the most. It is these elements that determine the general frameworks in which individuals can develop their entrepreneurship and seek new possibilities ${ }^{19}$. Entrepreneurship could not exist and develop without culture as "it is not "in culture" but "it itself is the culture ${ }^{20}$. This theory is confirmed by D. Lavoie ${ }^{21}$, who claims that entrepreneurship consists in interpreting and influencing culture. Moreover, he postulates that entrepreneurship is deeply rooted in and completely shaped by the culture. Similarly, B. Berger states that 'a type of cultural approach towards entrepreneurship enables the analysis of "grassroots", spontaneously increasing processes of economic growth. They are driven by the effort of individuals and social groups aiming to realise various aspirations, among which profit and improvement of one's own position compete with different aims ${ }^{\prime 22}$.

Every person's activity is formed by culture, which creates specific "social roots" of human activity. The dissociation from them - according to M. Bartnicki - is an "alarm

\footnotetext{
${ }^{17}$ T. Piecuch, Przedsiębiorczość. Podstawy teoretyczne, C.H. Beck, Warszawa 2013, p. 109.

${ }^{18}$ T. Gruszecki, Przedsiębiorca w teorii przedsiębiorczości, CEDOR, Warszawa 1994, p. 91.

${ }^{19}$ B. Berger (ed.), Kultura przedsiębiorczości, „Rój”, Warszawa 1994, p. 9.

${ }^{20}$ A. Szarecki, Przedsiębiorczość jako forma kultury, „Problemy Zarządzania” 2008, nr 2, p. 189.

${ }^{21}$ B. Berger (ed.), Kultura przedsiębiorczości, op. cit., pp. 17, 45.

${ }^{22}$ Ibidem, p. 30.
} 
bell" that cautions against an avalanche destroying hopes for entrepreneurial activity. The above mentioned author indicated the types of situations (activities, behaviour), within the broadly understood culture, which are not conducive to people's entrepreneurship. These $\operatorname{are}^{23}$ :

- confidentiality of information,

- lack of trust,

- a threat of losing identity,

- bureaucracy that blocks the explanation of the aims of undertaken actions,

- stubborn support of the concepts that led to success in the past,

- broadening the scope of power to make something good in the future,

- separation of the values that are considered important,

- multiplication of the priorities and guidelines that narrow discretion.

Thus, to ensure development, entrepreneurial and innovative attitudes and behaviour are necessary, however, they have to be established in culture and they must have social consent and support. The thesis on cultural establishment of social activities leads to the conclusion that legal regulations, access to technology and funds for financing activities are not sufficient for individuals, organisations and societies to be entrepreneurial. What is indispensable is a proper cultural foundation, which enables people to creatively use the chances and opportunities. Cultural factors, even though they change, have more permanent character than legal and economic conditions ${ }^{24}$. They are able to create a proper, positive climate around everybody who decides to become an entrepreneur. They perceive their activity as imitable, good practices that generate profits not only for entrepreneurs themselves but also for their closer and further environment.

\section{THE ROLE OF ORGANISATIONAL CULTURE IN CREATING CORPORATE ENTREPRENEURSHIP}

Entrepreneurship can refer to individuals, small and medium firms as well as to big, complex enterprises ${ }^{25}$. Quick changes that occur in their environment and the necessity for managing in more and more difficult conditions caused that also in big companies (frequently huge, international, global corporations) entrepreneurial behaviour is necessary at various levels - employees and the management. It is the so-called corporate entrepreneurship (also described as: organisational, internal, interorganisational or intrapreneurship $^{26}$ ). This notion was introduced to the literature on the subject in 1980s by G. Pinchot $\mathrm{III}^{27}$ owing to the publication Intrapreneuring. Why you don't have to leave the Corpora-

${ }^{23}$ M. Bratnicki, Przedsiębiorczość i przedsiębiorcy wspótczesnych organizacji, AE w Katowicach, Katowice 2002, p. 126.

24 B. Glinka, Kulturowe uwarunkowania przedsiębiorczości, kklinc.blox.pl/resource/SeminariumReferat Glinka.doc, [retrieved: July 3, 2014].

25 See more: T. Piecuch, Ewolucja teorii przedsiębiorczości - od przedsiębiorczości indywidualnej do wewnętrznej, [in:] „Uwarunkowania przedsiębiorczości - różnorodność i jedność”, K. Jaremczuka, ed., PWSZ w Tarnobrzegu, Tarnobrzeg 2010, pp. 476-494.

${ }^{26}$ A. S. Saetre, Intrapreneurship. An Exploratory Study of Select Norwegian Industries, Norwegian Research Concil, Trondheim 2001, p. 9,10.

${ }^{27}$ Already J. Schumpeter, who laid the foundation of the contemporary theory of entrepreneurship, claimed that the "spirit of entrepreneurship" is not necessarily identified with an individual - it can be felt in large enterprises or profit-oriented institutions. Also P. F. Drucker emphasised that contemporary companies, particularly large ones, will not survive in the period od quick changes and innovations if they do not acquire entrepreneur- 
tion to become an entrepreneur ${ }^{28}$. He assumed (on the basis of the observations of the functioning of big American enterprises) the possibility (or even, necessity) of entrepreneurial behaviour even in very big units with a complex structure. He comprehended intrapreneurship as 'a process by means of which huge enterprises aim to support entrepreneurship among the managers and other employees' ${ }^{29}$. Whereas, according to M. Bitz$\mathrm{er}^{30}$, intrapreneurship is a concept of supporting innovative processes in a big organisation in every area of its activity.

Thus, corporate entrepreneurship consists in doing new things, exceeding traditional methods in seeking new possibilities of activity. It is also a process in which individuals within a large structure of an organisation have the possibility of active, entrepreneurial activity, regardless of the resources they possess in a given moment ${ }^{31}$. F. L. Frey emphasises that the following elements influence the formation of corporate entrepreneurship ${ }^{32}$ :

- full involvement of corporation's management in the matters on propagating entrepreneurship,

- the appearance of intrapreneurship culture in the entire corporation and a determined model or type of activities characterised by entrepreneurship,

- a clearly determined, preferred profile of an intrapreneur,

- a defined system of rewards and incentives for an intrapreneur.

Ch. Stopford and J. Baden-Fuller distinguished three basic types of phenomena that create corporate entrepreneurship, namely ${ }^{33}$ :

- the creation of new economic units within existing corporations, which also comprises corporate venturing,

- transformation or renewal of already existing organisations, e.g., by means of process innovations, including new ways of solving old (familiar) problems,

- difficult to achieve, ground-breaking, exceptional innovations (called "frame-breaking" or "discontinuous changes") that change the rules of competing in the industry.

The development of corporate entrepreneurship necessitates a concurrence of a number of conditions, however, in the present paper particular regard has been paid to the significance of entrepreneurial culture, in which 'technocratic determinism is proposed to be replaced with a paradigm of subjective, active role of a person (entrepreneur, leader) engaged in the process of making choices on the basis of subjectively rational motivation

ial competence. Moreover, he claimed that it is not truth that large size constitutes a barrier for entrepreneurship and innovativeness. It is frequently heard in the discussions on entrepreneurship about bureaucracy in large organisations and their conservatism. Certainly, both of them exist and constitute a serious obstacle for entrepreneurship and innovativeness, however, it is the same degree as for other results. It is unambiguously indicated by the registers that amidst the existing enterprises, companies and institutions from public sector, the small ones are the least innovative and entrepreneurial. Whereas, there is a number of the existing entrepreneurial companies that are very large - source: P. F. Drucker, Natchnienie i fart czyli innowacja $i$ przedsiębiorczość, ,Studio Emka”, Warszawa 2004, pp. 168, 172.

${ }^{28}$ G. Pinchot III, Intrapreneuring. Why you don't have to leave the Corporation to become an entrepreneur, Harper \& Row Publishers, New York 1985.

${ }^{29}$ C. Barrow, The Essence of Small Business, Wyd. „Prentice Hall”, New York 1993, pp. 15 and the following.

${ }^{30}$ M. Bitzer, Intrapreneurship - Unternehmertum In der Unternehmung, Schaffer, Stuttgart 1991, p. 17.

31 A. Turró, Organizational resources and intrapreneurial activities: a cross-country study, http://idem.uab.es/2Turró_JPC_2012.pdf [retrieved: July 15, 2013].

${ }^{32}$ F. L. Frey, Entrepreneurship: A Planning Approach, West Publishing Company, 1993.

${ }^{33}$ A. S. Saetre, Intrapreneurship. An Exploratory Study of Selekt Norwegian Industries, op. cit., p. 9. 
basing on values. What is particularly meant here is the creation of an organisation's environment that is conducive to creative thinking, ${ }^{34}$. In such an entrepreneurial enterprise, the prevailing innovative atmosphere 'is created through ensuring a pro-innovative working environment, which enables risk-taking, experimenting and challenging patterns' ${ }^{35}$.

What plays a crucial role in corporate entrepreneurship are employees' entrepreneurial attitudes and behaviour. However, what is also necessary are certain solutions at organisational level that encourage workers to display initiative. All those aspects create the culture of intrapreneurship orientated towards innovativeness and proactivity not only at the level of employees but also organisation's management. According to Z. Jasiński, the following activities are conducive to entrepreneurial culture of an organisation ${ }^{36}$ :

- the support for every kind of novelty, improvement, innovativeness, creativity, imaginative people and the use of every opportunity to implement innovative solutions,

- open manifestation that the management at various levels are in favour of employees' creative initiatives and ideas, and simultaneously accept possible failures,

- tolerance of other, unconventional way of thinking and perceiving the world,

- tolerance of flexibility within the arranged schedules serving objectives' realisation; in certain situations lack of hurry in decision-making,

- effective communication, exchange and efficient flow of information between employees at various levels of management.

Intrapreneurial culture can be a counterbalance for excessive formalisation and bureaucracy; it supports employees' creative activity; it is orientated towards teamwork. In this type of culture "the place of such rules as "stay inconspicuous", "do not take initiative", "do not make mistakes", etc. are substituted with new principles that enable the development of imagination, formulation of long-term goals and plans of activity, rewarding the actions, attempts and experiments being undertaken ${ }^{37}$. Entrepreneurial employees in an intrapreneurial culture do not wait passively for superiors' orders - they themselves think what they should do and how they can achieve that. They have ideas, improve the procedure of manufacturing, improve products and are willing to cooperate with management, co-create entrepreneurship, feel like partners who are co-responsible for enterprise's condition - regardless of the position in the hierarchy they occupy. They are not satisfied with imitative work that does not require engagement, personal contribution and creativity, but they want to take responsibility for what they do, they do not avoid it - quite the opposite. They want the freedom of choice of the method of activity and the ways of solving problems (preserving, certainly, reasonable, safe proportions between freedom and discipline at work). Innovative achievements and employees' new ideas should be valued highly and adequately rewarded. The management should encourage employees to devel-

\footnotetext{
34 L. Kaliszczak, Kształtowanie kultury przedsiębiorczości oraz próba jej empirycznej weryfikacji, [in:] „Uwarunkowania przedsiębiorczości - różnorodność i jedność”, op. cit., p. 167.

35 D. Lewicka, W. Hydzik, Determinanty aktywności innowacyjnej: osobowość, kompetencje $i$ styl rozwiąywania problemów, wyniki badań, [in:] „Przedsiębiorczość - natura i atrybuty”, op. cit., p. 102.

${ }^{36}$ Z. Jasiński, Tworzenie środowiska dla zachowań przedsiębiorczych, [in:] „Kapitał ludzki a kształtowanie przedsiębiorczości", op. cit., p. 75 and the following.

${ }^{37}$ Ekonomika i zarządzanie mata firma, B. Piasecki, ed., PWE, Warszawa 1998, p. 31.
} 
op their own skills, to be creative; they should apply the so-called 'open style of implementing innovations, i.e. continuous and permanent positive attitude to innovations' ${ }^{38}$.

What is also significant in creating corporate entrepreneurship is suitable (being a result of organisational culture) atmosphere in an organisation. In such an atmosphere, employees are capable of taking initiatives; "they would feel like being active"; when they feel good in an organisation they will not be afraid if an idea occurs to be unsuccessful. And vice versa - employees will not engage or display initiatives in organisations in which 'there is a tendency to oppose everything that is new, which is usually expressed in generating false evaluations, rumours, emphasising and exaggerating the drawbacks and flaws of the proposed solutions, failing to mention their advantages, or even showing hostility towards people who suggest "new rules of the game", which usually requires putting more effort and breaking present habits ${ }^{39}$.

Employees should feel that their creative effort will be noticed, appreciated and adequately rewarded by the management. Only then will they be willing to display initiative and work on the implementation of new innovative solutions. In such an enterprise, having the trust and support of the management and co-workers they will feel safe $\mathrm{e}^{40}$.

To talk about the atmosphere that is conducive to entrepreneurship in an organisation one should ${ }^{41}$ :

- ensure good organisation of an institution (improvisation, activity or randomness always, in consequence, bode ill),

- make employees perceive themselves positively, feel an open chance and receive clear signals concerning their own success and good direction of personal development from the boss and the closest environment,

- give everybody real, not illusory chances of promotion, depending only on actual engagement and work results,

- invest in the development of employees' professional and personal competence through a suitable configuration of trainings, courses or postgraduate studies,

- provide the members of an organisation with permanent, unconditional support in various aspects (legal, organisational, emotional, moral and financial).

In view of this, the enterprises (regardless of the size) that take risk, are entrepreneurial, innovative and active ${ }^{42}$, create the conditions that encourage their employees to display entrepreneurial attitudes and behaviour. The significance of organisational culture for this process is manifested in its responsibility for certain activities, attitudes and motives, the manner in which an organisation as a team of people works and the way in which individ-

${ }^{38}$ B. Kaczmarek, Innowacje i kultura organizacyjna we wspótczesnym przedsiębiorstwie - zarys problemu, [in:] „Uwarunkowania przedsiębiorczości - różnorodność i jedność”, op. cit., p. 22.

${ }^{39}$ Z. Jasiński, Tworzenie środowiska dla zachowań przedsiębiorczych, op. cit. p. 75.

${ }^{40}$ Lack of trust in co-workers is considered one of the most significant barriers that curb employees' inclination towards entrepreneurship. It ensues from the following reasons: 1) a potential corporate entrepreneur feels lonely and knows that they will take responsibility for the entire realisation of a project (they cannot count on others); 2) an employee is afraid that if their ideas will be right, they can be adopted by co-workers; their author put the greatest amount of effort but the possible laurels can be reaped by someone else (e.g., superior) source: B. Glinka, S. Gudkova, Przedsiębiorczość, Oficyna Wolters Kluwer business, Warszawa 2011, p. 230.

${ }^{41}$ E. W. Radecki, Zachowania organizacyjne. Pytania i odpowiedzi, Wyższej Szkoły Integracji Europejskiej w Szczecinie, Szczecin 2010, p. 29.

${ }^{42}$ B. R. Barringer, A. C. Bluedorn, The relationship between corporate entrepreneurship and strategic management, op. cit. p. 422. 
uals function in a certain community. Furthermore, it contributes to the creation of a positive atmosphere that is conducive to entrepreneurship and innovativeness.

\section{CONCLUSION}

Presently, in more and more complicated conditions of external environment, there has been observed a great interest in the issues about the influence of organisational culture on human attitudes and behaviour. According to M. Czerska, it ensues from the fact that ${ }^{43}$ :

- the reserves of the growth of the effectiveness of people's functioning comprised in the so-called "hard" factors run out, therefore people started to seek additional sources in the area of the so-called "soft" factors, which encompass organisational culture;

- there was noticed and research-proved the influence of culture on the functioning of an organisation, its image, effectiveness, market position, etc.;

- people have started to perceive organisational culture as a kind of antidote for the problems that an organisation has to face and the challenges of the present time.

The paper aimed to indicate the significance of organisational culture in creating individual and corporate entrepreneurship. It has been emphasised that culture is a basis for every kind of activity, exists in every organisation and supports its activity. Understood as a set of prevailing values, human behaviour and the guidelines concerning the realisation of the fundamental objectives of a given organisational unit, it is also to a great extent responsible for the formation of entrepreneurial behaviour. It results from the fact that it has an effect on: communication, innovativeness, risk-taking, motivation to work, interpersonal relations - the elements that are crucial for the development of individual and also corporate entrepreneurship.

For the development of corporate entrepreneurship, organisational culture is even more significant since corporations, most frequently, are large, supranational enterprises employing the representatives of various cultures, possessing branches in various countries and doing business in various parts of the world. The awareness of the existence of cultural differences in various countries (which was emphasised by G. Hofstede) can considerably facilitate running a business and prevent many mistakes. It is not easy - it requires knowledge of intercultural management, however, it significantly facilitates the management of global corporations, which are growing in number under the conditions of globalisation.

\section{LITERATURE}

[1] Barreto H., The Entrepreneur in Microeconomic Theory: Disappearance and Explanation, Routledge, London and New York 1989

[2] Barringer B. R., Bluedorn A. C., The relationship between corporate entrepreneurship and strategic management, ,Strategic Management Journal” 1999, No 20

[3] Barrow C., The Essence of Small Business, Prentice Hall Ed., New York 1993

[4] Berger B. (ed.), Kultura przedsiębiorczości, „Rój”, Warszawa 1994

[5] Bitzer M., Intrapreneurship - Unternehmertum In der Unternehmung, Wyd. Schaffer, Stuttgart 1991

[6] Bratnicki M., Przedsiębiorczość i przedsiębiorcy wspótczesnych organizacji, AE w Katowicach, Katowice 2002

[7] Czerska M., Wptyw kultury na zachowania organizacyjne, [in:] „Przedsiębiorczość - natura i atrybuty”, K. Jaremczuka, ed., PWSZ w Tarnobrzegu, Tarnobrzeg 2012

\footnotetext{
${ }^{43}$ M. Czerska, Wptyw kultury na zachowania organizacyjne, [in:] „Przedsiębiorczość - natura i atrybuty”, op. cit., p. 20.
} 
[8] Drucker P. F., Natchnienie i fart czyli innowacja i przedsiębiorczość, „Studio Emka”, Warszawa 2004

[9] Ekonomika i zarzadzanie mała firma, pod red. B. Piaseckiego, PWE, Warszawa 1998

[10] Frey F. L., Entrepreneurship: A Planning Approach, West Publishing Company, 1993

[11] Hebert R. F., Link A. N., The Enterepreneur. Mainstream Views and Radical Critiques, Peaeger Special Studies, Praeger Scientific, New York 1982

[12] Hofstede G., Kultury i organizacje, PWE, Warszawa 2000

[13] http://geert-hofstede.com/poland.html

[14] Glinka B., Kulturowe uwarunkowania przedsiębiorczości, kklinc.blox.pl/resource/ SeminariumReferatGlinka.doc

[15] Glinka B., Gudkova S., Przedsiębiorczość, Oficyna Wolters Kluwer business, Warszawa 2011

[16] Gruszecki T., Przedsiębiorca w teorii przedsiębiorczości, CEDOR, Warszawa 1994

[17] Jasiński Z., Tworzenie środowiska dla zachowań przedsiębiorczych, [in:] „Kapitał ludzki a kształtowanie przedsiębiorczości”, M. Juchnowicz, ed., Poltext, Warszawa 2004

[18] Kaczmarek B., Innowacje i kultura organizacyjna we wspótczesnym przedsiębiorstwie - zarys problemu, [in:] „Uwarunkowania przedsiębiorczości - różnorodność i jedność”, K. Jaremczuka, ed., PWSZ w Tarnobrzegu, Tarnobrzeg 2010

[19] Kaliszczak L., Ksztattowanie kultury przedsiębiorczości oraz próba jej empirycznej weryfikacji, [in:] „Uwarunkowania przedsiębiorczości - różnorodność i jedność”, K. Jaremczuka, ed., PWSZ w Tarnobrzegu, Tarnobrzeg 2010

[20] Kisielnicki J., Zarzadzanie. Jak zarzadzać i być zarzadzanym, PWE, Warszawa 2008

[21] Koźmiński A. K., Jamielniak D., Zarzadzanie od podstaw, Oficyna Wolters Kluwer business, Warszawa 2011

[22] Lewicka D., Hydzik W., Determinanty aktywności innowacyjnej: osobowość, kompetencje i styl rozwiązywania problemów, wyniki badań, [in:] „Przedsiębiorczość - natura i atrybuty”, K. Jaremczuka, ed., PWSZ w Tarnobrzegu, Tarnobrzeg 2012

[23] Piecuch T., Ewolucja teorii przedsiębiorczości - od przedsiębiorczości indywidualnej do wewnętrznej, [in:] „Uwarunkowania przedsiębiorczości - różnorodność i jedność”, K. Jaremczuka, ed., PWSZ w Tarnobrzegu, Tarnobrzeg 2010

[24] Piecuch T., Przedsiębiorczość. Podstawy teoretyczne, C.H. Beck, Warszawa 2013

[25] Pinchot G. III, Intrapreneuring. Why you don't have to leave the Corporation to become an entrepreneur, Harper \& Row Publishers, New York 1985

[26] Pocztowski A., Rola systemu zarzadzania kapitatem ludzkim w ksztattowaniu przedsiębiorczości. Narzędzia zarzadzania kapitałem ludzkim kreujące postawy przedsiębiorcze, [in:] „Kapitał ludzki a kształtowanie przedsiębiorczości”, M. Juchnowicz, ed., Poltext, Warszawa 2004

[27] Radecki E. W., Zachowania organizacyjne. Pytania i odpowiedzi, Wyższa Szkoła Integracji Europejskiej w Szczecinie, Szczecin 2010

[28] Rozkwitalska M., Problemy zarządzania międzykulturowego w przedsiębiorstwach z kapitatem zagranicznym, „Problemy Zarządzania” 2009, nr3

[29] Saetre A. S., Intrapreneurship. An Exploratory Study of Select Norwegian Industries, Norwegian Research Concil, Trondheim 2001

[30] Schein E. H., Organizational Culture and Leadership, John Wiley \&_Sons Publisher, San Francisco 2004

[31] Sułkowski Ł., Ewolucjonizm w zarządzaniu. Menedżerowie Darwina, PWE, Warszawa 2010

[32] Sułkowski Ł., Kulturowa zmienność organizacji, PWE, Warszawa 2002

[33] Szarecki A., Przedsiębiorczość jako forma kultury”, „Problemy Zarządzania” 2008, nr2

[34] Turró A., Organizational resources and intrapreneurial activities: a cross-country study, http://idem.uab.es/2Turró_JPC_2012.pdf 


\section{KULTUROWE UWARUNKOWANIA ROZWOJU PRZEDSIĘBIORCZOŚCI INDYWIDUALNEJ I KORPORACYJNEJ}

W artykule skoncentrowano się na charakterystyce dwóch rodzajów przedsiębiorczości - indywidualnej i korporacyjnej. Ich rozwój jest rezultatem splotu różnorodnych czynników, zależnych zarówno od wewnętrznych (podmiotowych) predyspozycji konkretnych osób podejmujących działalność gospodarczą na własny rachunek (przedsiębiorczość indywidualna) oraz realizujących przedsiębiorcze przedsięwzięcia (przedsiębiorczość korporacyjna), jak również od warunków zewnętrznych wyznaczających tempo rozwoju przedsiębiorczości, wpływających na skuteczność tego typu działań. W opracowaniu szczegółowej analizie poddano kulturowe uwarunkowania rozwoju przedsiębiorczości indywidualnej i korporacyjnej. Autorki opracowania zwracają w nim uwagę na fakt, że analiza przedsiębiorczości (zarówno teoretyczna, jak i empiryczna) nie może pomijać jej związków z kulturą, która stwarza solidne fundamenty każdego rodzaju aktywności człowieka, działalności przedsiębiorczej również. Przedsiębiorczość jest procesem społecznym bardzo silnie zdeterminowanym kulturowo. Zależy od wzorów, wartości ukształtowanych historycznie, także na szczeblu rodziny i społeczeństw lokalnych. Już J. Schumpeter wskazywał na to, że rozwój przedsiębiorczości wymaga sprzyjającego klimatu społecznego. Współcześnie uwarunkowaniom kulturowym rozwoju każdego rodzaju przedsiębiorczości przypisuje się fundamentalną rolę. Podkreśla się, że przedsiębiorczość głęboko zakorzeniona jest w kulturze oraz całkowicie przez nią kształtowana. Uwarunkowania kulturowe odgrywają bardzo ważną rolę także dlatego, że przedsiębiorczość realizowana jest w określonych realiach społecznych, wynika z ukształtowanych społecznie wzorów zachowań, sposobów myślenia oraz poznawania świata, z samej natury człowieka - przedsiębiorcy. Analiza przedsiębiorczości (także indywidualnej i korporacyjnej) nie może zatem pomijać jej związków z kulturą.

Słowa kluczowe: przedsiębiorczość, przedsiębiorczość indywidualna, przedsiębiorczość korporacyjna, kultura organizacyjna

DOI: $10.7862 /$ rz.2015.mmr.57

Tekst złożono w redakcji: lipiec 2015

Przyjęto do druku: grudzień 2015 